\title{
To Govern in the Interest of the Corporation: What Is the Board's Responsibility to Stakeholders Other than Shareholders?
}

\author{
Yvan Allaire $^{1}$ \& Stéphane Rousseau ${ }^{2}$ \\ ${ }^{1}$ Institute for Governance of Public and Private Organizations, Montréal, Canada \\ ${ }^{2}$ Faculty of Law, Université de Montréal, Montréal, Canada \\ Correspondence: Stéphane Rousseau, Faculty of Law, Université de Montréal, P.O. Box 6128 Dowtown Station, \\ Montréal, Qc., Canada, H3C 3J7. Tel: 1-514-343-7627. E-mail: stephane.rousseau@umontreal.ca
}

\author{
Received: June 21, $2015 \quad$ Accepted: July 15, 2015 Online Published: August 28, 2015 \\ doi:10.5539/jms.v5n3p1 URL: http://dx.doi.org/10.5539/jms.v5n3p1
}

\begin{abstract}
In Canadian business law, directors have a duty to act in the best interest of the corporation, which includes the duty to assess, fairly and equitably, the impact of the corporation's actions and decisions on its stakeholders.

But which of the stakeholders' expectations should be taken into account? How should a board arbitrate between the divergent expectations of different stakeholders? How should the interests of the shareholders be weighed in relation to the interests of the other stakeholders? Ultimately, in whose interests should the directors exercise their responsibility to govern the corporation's affairs?

This text attempts to provide answers to these questions, which are deeply perplexing to many directors, by reviewing the relevant law in other jurisdictions, particularly Great Britain and the United States, and then parsing the relevant judgments of the Canadian courts. We also provide guidelines for a board's decision process when several stakefolders may be impacted by a decision or action of the company.
\end{abstract}

Keywords: Canadian business law, corporate governance, stakeholders

\section{Introduction}

The measure of a business corporation's success is undoubtedly its economic performance. However, to achieve an excellent performance in the long run, the corporation must make the best use of the talent and experience of all its personnel. It must protect its good reputation as an employer, supplier of goods and services, buyer and citizen of the regions and countries where it operates.

At some point in time, this statement would have been considered a truism.

Indeed, this concept of the corporation was dominant among large enterprises all through the 1950s to the 1980s. At that time, corporate executives and boards of directors were imbued with a responsibility for a broad spectrum of stakeholders. They sought to maintain a healthy balance between the interests of the employees, shareholders, clients, and the broader societyeneral. Financial markets, and the shareholders in particular, had relatively little influence on the decisions of a large corporation when share ownership was fragmented and its financing came largely from internally generated funds.

Under the best circumstances, this kind of industrial arrangement produced excellent companies during that period: IBM, Dupont, GM and many others in the United States; Bell Canada, Alcan, the Canadian chartered banks, Canadian Pacific and others in Canada (Allaire \& Firsirotu, 1993).

Whatever the legal stipulations about boards' fiduciary responsibility may have been during the 1950s to 1980s, management and boards of directors (made up at the time of a majority of insiders drawn from management) were driven by a concept of the corporation that took the interests of the stakeholders into account just as much as those of the shareholders.

\subsection{A Change in Context}

At the beginning of the 1980s, several changes brought about a gradual erosion of this corporate model of reciprocal loyalty and concern for all "stakeholders". One after another, large corporations repudiated their psychological, social and economic contract with their employees and civic society. The essential "clauses" of 
this contract: trade-off between the interests of various stakeholders, stability of employment, promotions from within, and compensation based on merit and fairness, have been subjected to a relentless assault.

Over time, as 1. Investment funds of all kinds became the "majority" shareholders of stock-exchange listed corporations; 2. Boards of directors became populated, in accordance with the governance orthodoxy, by a majority of independent members; and 3. Corporate executives were increasingly compensated with stock options and other stock-related incentives, financial markets became the corporation's dominant stakeholder, sometimes the only relevant one.

As institutional funds became the majority shareholders of the large corporations, they wanted to be treated as the "owners" of the business. To align the interests of the executive officers with those of the shareholders, executives were paid largely with stock options and other variable compensation linked to the share price; this form of compensation turned out to be extremely advantageous, provided one did all what one could to boost the company's share price.

Once again, regardless of what were the legal fiduciary responsibilities of the board, board members came to understand that they were primarily responsible for "maximizing shareholder value".

Thus, for the last 30 years, the "creation of value for the shareholder" has become the leitmotif and imperative in the governance of public corporations in Anglo-Saxon countries.

Yet, the Canada Business Corporations Act (CBCA), the governing law, decrees that the responsibility of boards of directors is to act in the best interests of the corporation (Note 1). The Supreme Court of Canada interpreted the scope of this responsibility in two relatively recent judgments: Peoples Department Stores Inc. (Trustee of) $v$. Wise (2004) and BCE Inc. v. 1976 Debentureholders (2009).

These two judgments are peremptory: the board must not grant any preferential treatment in its decision-making process to the interests of the shareholders or any other stakeholder, but must act exclusively in the interests of the corporation of which they are the directors.

However, neither the CBCA, nor the judgments of the Supreme Court offer boards of directors any guidelines to clarify the practical application of these statements in concrete situations. Thus, when the interests of various stakeholders are opposed, how should the interests of the corporation be understood? How should the board proceed in determining a fair trade-off between the interests of various stakeholders, and which of them are entitled to such consideration?

This text attempts to answer these questions, which are of crucial importance for all board members of publicly listed corporations in Canada.

\section{The Duty to Act in the Best Interest of the Corporation}

In whose interest must the directors exercise their authority to oversee the corporation's affairs? This central issue of governance has been debated in the literature and case law for more than a century. According to the classical approach, which is supported by one school of thought in financial economics, the directors must act in the interests of the shareholders.

Since the start of the $21^{\text {st }}$ century, successive financial scandals, notorious cases of corporate social irresponsibility and the 2008 financial crisis have cast serious doubt on the shareholder primacy model. Several authors and practitionners have proposed a concept of the socially responsible corporation mixing in an enlightened manner the interests of several stakeholders. As we shall see below, Anglo-American corporate law is also evolving toward a broader concept of the corporation's interests.

\subsection{The Best Interest of the Corporation Based on the Primacy of Shareholders}

In Anglo-American corporate law, the duty to act in the interest of the corporation has traditionally been interpreted to mean that the directors had to act in the interests of the shareholders. (Peoples Department Stores Inc. (Trustee of) v. Wise) (Greenhalgh v. Ardene Cinemas, 1951) (Palmer v. Carling O'Keefe Breweries of Canada Ltd., 1989) (Re Olympia \& York Enterprises and Hiram Walker Resources Ltd., 1986) (Sealy, 1996, p. 11). For example, in the United Kingdom, in the case of Greenhalgh v. Ardene Cinemas Ltd. (1951), the court held that the words "the company as a whole does not (at any rate in such case as the present) mean the company as a commercial entity distinct from the corporators. It means the corporators as a general body." (Greenhalgh, p. 291). In other words, the corporation consisted of an entity comprised of all the shareholders.

Similarly, before the Supreme Court decision in Wise, the Quebec Court of Appeal echoed those words when it remarked that [translation] "generally speaking, the corporation's interests intersect with the interests of the shareholders as a whole because the achievement of the corporation's objects is, in principle, the rationale for the 
pooling of the invested sums". The Court of Appeal added that [translation] "assuming that the shareholders seek to achieve the objects of the corporation, one can conclude that the will of the shareholders and the interests of the corporation usually coincide." (Peoples at paras 66-67).

Finally, in the eBay decision (Ebay Domestic Holdings, Inc. v. Newmark, 2010), the Delaware Court of Chancery recently stressed the importance of the nature of the corporation in defining the corporate interest based on the interests of the shareholders: "Having chosen a for-profit corporate form, the Craigslist directors are bound by the fiduciary duties and standards that accompany that form. Those standards include acting to promote the value of the corporation for the benefit of its stockholders." (Ebay, p. 34) (Note 2).

The traditional conception of the directors' duty of loyalty is summarized in Figure 1. (Gray, 2005, pp. 184, 193 \& 194) According to this conception, the directors' duty of loyalty is directed to the corporation. This duty requires that they act in the interests of all the shareholders.

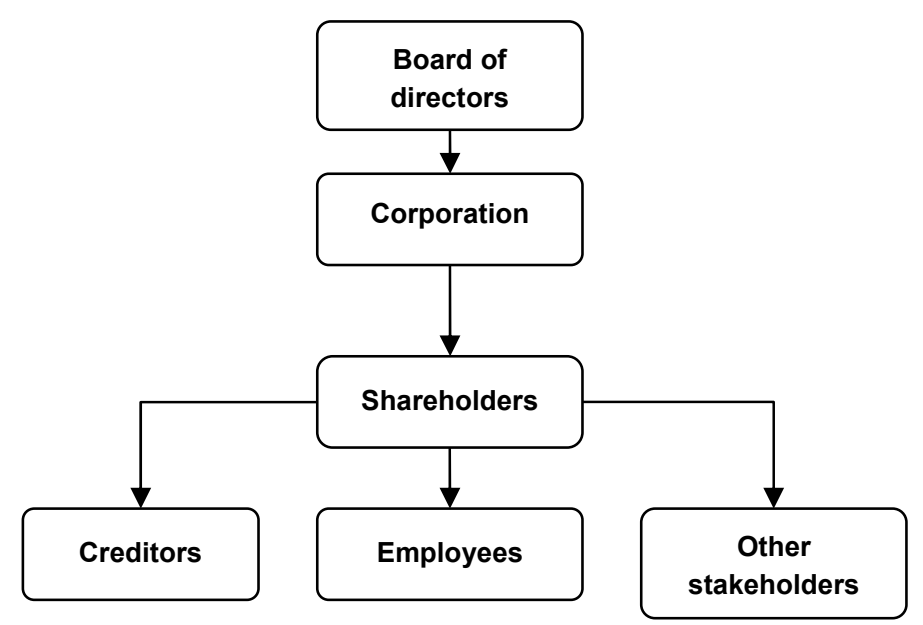

Figure 1. The traditional interpretation of directors' fiduciary duties

Strictly interpreted, the approach equating the corporation's interests with those of the shareholders has led the courts to rule that the directors should only make their decisions based on this objective, and disregarding any other consideration. For example, in Parke v. Daily News Ltd. (1962), the British Court of Chancery noted that it was not within the authority of the directors to worry about the welfare of the employees, unless there was an incidental benefit to the shareholders.

The strict interpretation of the directors' duty of loyalty has however remained marginal. According to leading authorities, the obligation to act in the shareholders' interests must be assessed from a broad perspective that does not prevent the directors from taking the interests of the corporation's other stakeholders into account (Keay, 2013, p. 112) (Lizée, 1989, pp. 666-671) (McGuinness, 2007, pp. 971 and following) (Note 3). The interests of the shareholders are the primary purpose that is supposed to guide the directors' decisions. But to achieve this primary purpose, the directors will certainly have to make decisions that will also be beneficial for other constituents. As Professor Gower noted: "Even if, in a going concern, the company's interests are those of the shareholders [...] it will do the shareholders no good if the company has dissatisfied customers, faces an antagonistic central or local government and has angry pressure groups disrupting its annual meetings." (Davies, 1997, p. 604). Thus, making a decision that simultaneously benefits the shareholders and the employees or consumers does not constitute a breach of the directors' duty of loyalty. On the other hand, the directors may not put aside the shareholders' interests in favour of other stakeholders.

Moreover, it should be noted that the duty to act in the interests of all the shareholders is not restricted by a time period (Note 4). The expression "all the shareholders" includes the interests of present and future shareholders: "This implies that there is no equation between the interests of the company and its sole shareholder or all its present shareholders because one must also take into account the interests of those who may eventually hold shares. (Lizée, 1989, p. 668) (McGuinness, 2007, p. 972). The directors' duty of loyalty may therefore be interpreted to mean that the directors must act in the interests of present and future shareholders, thereby giving a long-term perspective to this duty. Thus, directors have the latitude to make decisions that do not maximize the 
corporation's short-term profits to the extent that these decisions benefit the shareholders in the long term (Note $5)$.

In closing, it should be noted that there is a lack of clarity as to the meaning of "shareholders' interests" (Keay, 2013, pp. 25-28). The use of derivative products can transform shareholders' economic interests by sometimes making them totally indifferent to the results of the corporation, or by hiding their true interest $(\mathrm{Hu}, 1991)(\mathrm{Hu} \&$ Black, 2006) (Note 6). The difference between the record date and the date of the vote also allows for arrangements to be made that affects the composition of the shareholder base. Similarly, the coexistence of different share classes raises difficulties in determining the shareholders' interests. Thus, in the modern world of finance, the concept of the shareholders' interests becomes somewhat murky and relative; it is not necessarily synonymous with the interest of the corporation (Hu, 1991, p. 1287).

\subsection{The Best Interest of the Corporation Defined as the Firm's Long-Term Interest}

\subsubsection{Canadian Law}

In the Wise and $B C E$ decisions, the Supreme Court scrapped the concept of the corporate interest based on the shareholders' primacy. In those cases, the Court proposed an interpretation of the corporation's interest which emphasizes the corporation's status as a distinct legal person. According to the Court, "the directors' duty is clear-it is to the corporation." (BCE Inc. at para. 37) (1394943 Ontario Inc. v. Roy, 2009). This means that the interests of the corporation are not to be confused with the interests of the shareholders, creditors or those of any other stakeholders (Peoples Department Stores Inc. (Trustee of) v. Wise, 2004, at para. 43). Thus, the directors always owe their duty of loyalty to the corporation, a legal entity distinct from the stakeholders (Gray, 2005, pp. 184, 193-194).

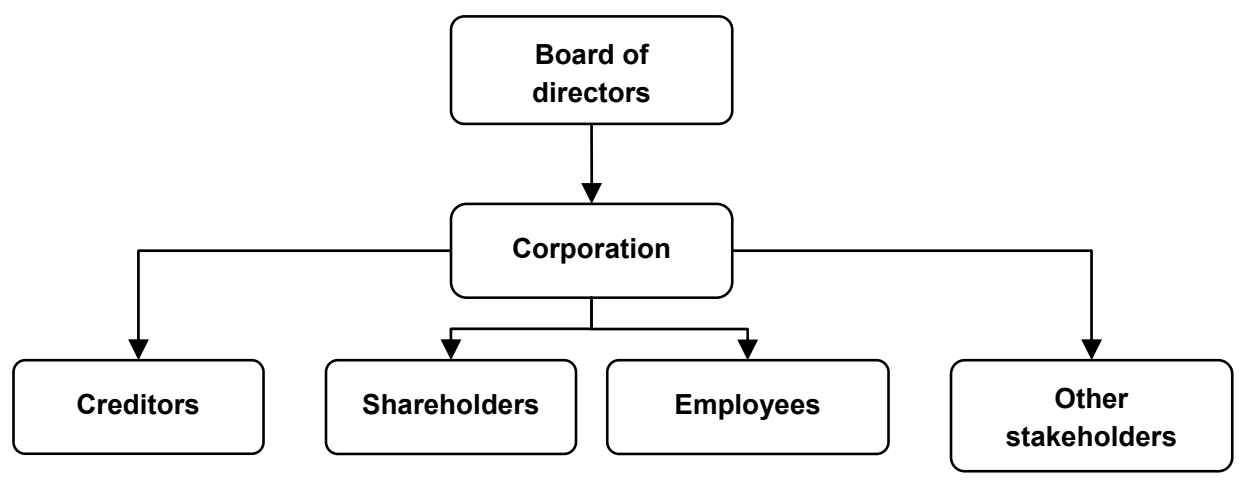

Figure 2. The new interpretation of directors' fiduciary duties

The corporation's interest is a broad and contextual concept. Since it concerns an entity with a perpetual existence, this concept applies to the long-term interest of the corporation as an ongoing concern. For this reason, according to the Supreme Court, the duty of loyalty "is not confined to short-term profit or share value." (BCE Inc. at para. 38). According to the Court, from an economic standpoint, this concept refers to "the maximization of the value of the corporation". In more simple terms, it requires the directors to act in a manner that makes the corporation a "better corporation" (Peoples at para. 41).

The reference to the maximization of the value of the corporation suggests that the Supreme Court sought to take into account the diversity of the interests that are combined in the corporation (Millon, 2011, p. 530 and following) (Note 7). In doing so, it refused to confine the interests of the corporation to shareholder value. This clarification is important because the notion that interest of the corporation is tantamount to its share price has led to major distortions in decision making and has been the object of scathing criticism (Note 8) (Lazonick\& O'Sullivan, 2000): "Creating 'shareholder value' has become the mantra of corporate management.Motivated by large incentive compensation linked to stock price, management would likely resort to all legitimate means to create value for shareholders" (Allaire \&Firsirotu, 2009, p. 137).

However, the Supreme Court refrained from proposing a definition of the value of the corporation. From a financial standpoint, this concept could be interpreted on the basis of the corporation's financial securities, i.e. the shares and debt securities (Note 9). 
In fact, in financial theory, the value of a corporation is determined by the present value of future cash flows. This notion of value, which is conceptually impeccable, raises two critical issues: 1 . The estimation of cash flows for several years into the future, an uncertain operation under the best of circumstances; 2. The determination of the appropriate rate to discount the future cash flows of a specific business over a specific time period given the risk associated with the realization of these cash flows. This determination can be subject to significant divergences that can lead to highly variable assessments of the corporation's value. However, this definition of value has the merit of capturing the effect of factors that are deferred in time, as well as changes in the level of risk as a result of decisions made by the board.

This measure of value is entirely compatible with the consideration of the long-term interests of significant stakeholders.

Indeed, by acting in the interests of the corporation, the directors will, by the same token, be making decisions that generally benefit all the stakeholders in the long term. In certain circumstances, their decisions will however make winners and losers of some of the stakeholders. The Supreme Court recognized this reality in the $B C E$ decision, noting that, even in these cases, the duty of loyalty was owed to the corporation and not to stakeholders. At the same time, it noted that there was no principle "that one set of interests-for example the interests of shareholders - should prevail over another set of interests" of stakeholders (BCE Inc. at para. 84).

However, the Court refrained from formulating instructions to guide the directors in making trade-offs among divergent interests, leaving this issue to their business judgment. The Supreme Court emphasized the corporation's interest as those of an on-going legal entity. This necessarily translates into a long-term perspective in decision making. By stressing this perspective, the Supreme Court's approach goes beyond a zero-sum analysis in which trade-offs are made of costs and benefits to shareholders and stakeholders in the short term (Millon, 2011, p. 530 and following).

In closing, it is interesting to note that the impact of the $B C E$ decision on the directors' duty of value maximization was considered in the Quebec case of Brassard c. Forget (2010). In that decision, the Superior Court noted that the directors' duty of loyalty in the context of a change of control transaction is not limited [translation] "to only considering the interests of the shareholders or the immediate growth in the value of the shares" (Brassard at para. 161). Thus, [translation] "favouring the sustainability of the company is an eminently relevant objective and valid in the context of the company as an ongoing concern" (Brassard at para. 161). These comments echo the teachings of the Supreme Court when it held that the directors' duty of loyalty does not consist of maximizing short term share value. The corporation's interests may dictate other outcomes than a sale to the highest bidder. In that particular case, the sustainability and continuity of the company took precedence as an objective, rather than the maximization of short-term value in a context in which the bidder was not on a solid financial footing to carry through with the acquisition.

\subsubsection{U.S. Law}

Beyond Delaware, the constituency statutes, adopted during the 1980s and early 1990s by some 30 U.S. states, are influencing the directors' duty of loyalty and the definition of the corporation's interest. (Mitchell, 1992) (Symposium: "Corporate Malaise-Stakeholder Statutes: Cause or Cure?", 1991). These special statutes have modified corporate law by recognizing the authority of the directors to consider the interests of the other stakeholders in decision making. For example, since the adoption of such legislation, the corporate business statute in Pennsylvania states as follows: (Note 10)

\section{$\S 1715$. Exercise of powers generally}

(a) General rule.- In discharging the duties of their respective positions, the board of directors, committees of the board and individual directors of a business corporation may, in considering the best interests of the corporation, consider to the extent they deem appropriate:

(1) The effects of any action upon any or all groups affected by such action, including shareholders, employees, suppliers, customers and creditors of the corporation, and upon communities in which offices or other establishments of the corporation are located.

(2) The short-term and long-term interests of the corporation, including benefits that may accrue to the corporation from its long-term plans and the possibility that these interests may be best served by the continued independence of the corporation.

(3) The resources, intent and conduct (past, stated and potential) of any person seeking to acquire control of the corporation. 
(4) All other pertinent factors.

Clearly, this provision bears a strong resemblance to the Supreme Court of Canada's position in Wise. In fact, one would be tempted to consider that the Court has judicially created a situation similar to that existing under Pennsylvanian corporate law. (Note 11)

In addition, the Pennsylvanian legislation provides as follows:

(b) Consideration of interests and factors.-The board of directors, committees of the board and individual directors shall not be required, in considering the best interests of the corporation or the effects of any action, to regard any corporate interest or the interests of any particular group affected by such action as a dominant or controlling interest or factor $[\ldots]$

Here again, this provision is echoed in the Wise decision where the Court states that the directors must not give preponderance to the interests of a stakeholder.

According to a majority of commentators, the amendment of the Pennsylvania corporate legislation to all intents and purposes had the effect of preventing the application of the Revlon duties which hold that, when a change in control is imminent, the directors must maximize the short-term value of the shares (Orts, 1992, pp. 109-110) (Nickerson, 1998, p. 1380) (Springer, 1999, p. 98) (Wallman, 1991, pp. 186-187). In other words, the objective guiding the directors is no longer transformed in the context of a change of control (Keyserv.Commonwealth National Financial Corp., 1987). In addition, the constituency statutes broadened the directors' sphere of discretion in terms of defensive measures. Indeed, in states with constituency statutes, the courts have found that concern over the impact of the bid on the stakeholders as a whole could form the legitimate basis of a defensive measure (Keyser, 1987) (Baron v. Strawbridge, 1986) (Note 12).

\subsubsection{English Law}

In the United Kingdom, following an important reform of the corporate law, the Companies Act 2006 incorporated the principle of enlightened shareholder value (ESV) into the directors' duties (Keay, 2013). Section 172(1) codifies this principle in the expression "Duty to promote the success of the company", which is associated with the directors' duty to act in the interests of the company.

172 Duty to promote the success of the company

(1) A director of a company must act in the way he considers, in good faith, would be most likely to promote the success of the company for the benefit of its members as a whole, and in doing so have regard (amongst other matters) to-

(a) the likely consequences of any decision in the long term,

(b) the interests of the company's employees,

(c) the need to foster the company's business relationships with suppliers, customers and others,

(d) the impact of the company's operations on the community and the environment,

(e) the desirability of the company maintaining a reputation for high standards of business conduct, and

(f) the need to act fairly as between members of the company.

The duty to promote the success of the company is a controversial one that has been the subject of numerous comments by authors endeavouring to set the parameters thereof. In the absence of significant judicial decisions, the true scope of this duty still remains uncertain. Nevertheless, based on the literature, we can sketch the outlines of this duty.

From the outset, the central notion of "success" is defined with a long-term perspective in mind. In the parliamentary proceedings surrounding the adoption of the Companies Act 2006, it was noted that "[f]or a commercial company, success will usually mean long-term increase in value." (Keay, 2013, p. 108, citing Lord Goldsmith in the parliamentary debates) Acknowledging the relevance of the long-term perspective, Professor Keay added that the success of the company could consist of achieving its business objectives, which, among others, may be financial or strategic in nature (Keay, 2013, p. 109). In any event, the success of the company is assessed from the standpoint of the shareholders.

When the directors act to promote the company's success, section 172(1) requires that they have regard to a non-exhaustive set of factors which are of interest to the stakeholders (Note 13). The expression "have regard to" is ambiguous and has been interpreted in various ways. According to some observers, the expression means that 
the directors must be systematically aware of the enumerated factors and consider them in making their decision which identifies the solution that is best able to promote the success of the company (Davies, 2007, at para. 6.38). In Professor's Keay words: "So, directors are not entitled merely to take any approach to achieving an end result which they believe will promote the success of the company. They should consider how the end result can be accomplished and in doing this the interests of the constituencies come into play." (Keay, 2013, p. 128)

The Companies Act 2006 provides no indication of how one is to balance the various factors when conflicts arise Balancing is therefore a matter for the discretion of the directors in accordance with their duty to promote the success of the company for the benefit of the shareholders (Keay, 2013, pp. 134-135). Insofar as they resolve the conflicts with care, diligence and in good faith, the directors should benefit from judicial deference (Beale, 2007).

Ultimately, the duty to promote the success of the company imposes an obligation on the directors to consider the interests of the stakeholders in their decision making. In this regard, English law is more demanding than Canadian law, which only authorizes the directors to consider their interests. However, the Companies Act 2006 maintains the classical approach pursuant to which the shareholders' interests remain the objective that the directors must pursue (Keay, 2013, p. 216). It is distinguished from Canadian law in which the corporation's interests are viewed from the perspective of the legal entity and not just the shareholders.

\subsection{Summary}

Since the Peoples and $B C E$ decisions, the directors' duty of loyalty has been assessed from the standpoint of the corporation as a legal person. This duty imposes the obligation to act in the interests of this legal person, which is comprised of a group of stakeholders. This conception of the corporation's interests, which is echoed to some extent in the United States and the United Kingdom, seeks to take account of the fact that corporate governance is not limited solely to taking care of shareholders' interests even though only shareholders elect board members.

Corporate governance is more than simply managing the relationship between the firm and its capital providers. Corporate governance also involves how the various constituencies that define the business enterprise serve, and are served by, the corporation. Implicit and explicit relationships between the corporation and its employees, creditors, suppliers, customers, host communities - and relationships among these constituencies themselves - fall within the ambit of a relevant definition of corporate governance (Bradley, Shipani, Sundaram, \& Walsh, 1999, p. 11).

In practical terms, Canadian law has clearly established the legitimacy, for boards of directors, to seek to maximize the value of the corporation over the long term.

Canadian law and Supreme Court decisions also confirm the legitimacy of the stakeholders' interests in the directors' decision making. The Supreme Court has expressly authorized the directors to consider the interests of the stakeholders when exercising their decision-making authority, on the same basis as the interests of the shareholders.

\section{The Decision-Making Process of Boards of Directors under Canadian Laws}

Under Canadian corporate law, the directors have the duty to act in the interest of the corporation. In light of Canadian case law, the directors cannot restrict their definition of the corporation's interests to the interests of the shareholders alone. According to the $B C E$ and Wise decisions, the directors' duty consists of maximizing the value of the corporation in a long-term perspective, and in the context of the corporation as an ongoing concern. In pursuing this objective, the directors, under prevailing case laws, are authorized to consider the interests of stakeholders.

In addition to setting the objective that should guide the directors, corporate law provides a framework for their decision-making process. Thus, directors have the duty to act with care when exercising their authority. Furthermore, they are subject to an obligation of fair treatment in making decisions. We intend to show that the concept of the interests of the corporation requires the board of directors to adopt a decision-making process that is sensitive to the interests of stakeholders.

\subsection{Duty of Care}

\subsubsection{The General Standard of Conduct}

The directors are required to act with care in performing their duties (Note 14). This standard of conduct has an objective component which requires the conduct of the directors in question to be assessed according to the standard of the reasonable person. By referring to this standard, the law does not impose a specific degree of care as it does in professional matters in which the person in question must act in the same manner as a reasonably 
careful professional would. It is sufficient for the director to act as a reasonably prudent person would in order to avoid errors and minimize the risks of damage.

The duty of care requires directors to conduct themselves as a reasonable person would in "comparable circumstances". As the Supreme Court has noted, this expression does not introduce a subjective dimension into the analysis of the directors' conduct that would allow for the assessment of their personal characteristics and motivations (Peoples, at para. 63). It only allows the circumstances of the factual context in which the directors were acting to be taken into account.

The expression "in comparable circumstances" justifies the consideration of the "prevailing socio-economic conditions". According to the Supreme Court, this expression encompasses corporate governance best practices: " $[\mathrm{t}]$ he emergence of stricter standards puts pressure on corporations to improve the quality of board decisions." (Peoples, at para. 64). In light of the concept of corporate interest laid down in Peoples and BCE, best practices should not be limited to those that are developed with a view to promoting the shareholders' interests. Insofar as the directors must act in the best interests of the corporation "as a responsible corporate citizen", the expression "in comparable circumstances" should permit the consideration of exemplary practices relating to the social responsibility of corporations and sustainability, including the codes of conduct voluntarily adopted by corporations (Reiter, 2009, pp. 650-652) (Note 15).

In a nutshell, the requirements arising from the objective standard of care could be enhanced when these practices create higher expectations. Since they are contextual in nature, the standards and practices of governance are not automatically included in the standard of care, according to the case law. (Greenlight Capital Inc. v. Stronach, 2006, at para. 61).Thus, it is up to the party alleging the breach of the duty of care to prove that the governance practices were included in the standard of conduct. Only in such a case can a transgression of these practices constitute careless or negligent conduct.

\subsubsection{Duty to Inform Oneself}

In order to fulfill the duty of care, the directors are under an obligation to adequately inform themselves in regard to the decision to be made by obtaining all the material information reasonably available in the circumstances. (UPM-Kymmene Corp. v. UPM-KymmeneMiramichi Inc. (hereinafter Repap), 2002) (Note 16). The obligation to inform oneself is summarized in the following terms by the Ontario Court of Appeal in Pente Investment Management Ltd. v.Schneider Corp. (1998): "The mandate of the directors is to manage the company according to their best judgment; that judgment must be an informed judgment; it must have a reasonable basis." (Pente Investment Management Ltd. at pp. 253, 264-265) (Unique Broadband Systems, Inc. (Re), 2013, at para. 36).

The development of the obligation to inform oneself owes much to the decision in Smith v. Van Gorkom of the Delaware Supreme Court. (1985) (Note 17). In that case, Mr. Van Gorkom, the CEO of Trans Union, had called an urgent meeting of the board of directors. At the meeting, Mr. Van Gorkom gave a presentation on a merger proposal for Trans Union. He summarily explained the transaction and submitted the proposed price for the shares of Trans Union. After two hours of discussions, the board of directors approved the transaction without having the opportunity to review the details of the merger, or seek an independent appraisal of the price offered for the shares. The Delaware Supreme Court held that Trans Union's directors had been grossly negligent by failing to inform themselves of the role of Mr. Van Gorkom in the sale of the corporation, and of the value of the corporation, when there was no reason for proceeding so quickly (Smith v. Van Gorkom, 1985, p. 874).

In Canada, the Smith v. Van Gorkom decision has had a strong impact in matters involving change of control transactions. In that context, the courts have ruled that in order to fulfill their obligation to inform themselves, the directors may seek the advice of independent financial and legal advisors ( $\mathrm{CW}$ Shareholdings Inc. v. WIC Western International Communications Ltd., 1998) (Re Olympia \& York Entreprises Ltd.v. Hiram Walker Resources Ltd., 1986). Where they rely in good faith on the advice of their advisors, the directors benefit from specific protection under corporate law (Blair v. Consolidated Enfield Corp., 1995) (Armstrong World Industries Inc. v. Arcand, 1997) (Raffo c. Teknorordinateursindustriels Inc, 2000) (Westfair Foods Ltd. v. Watt, 1990). Still, in the past few years, the courts have held that the directors could not consider that they had automatically fulfilled their obligation to inform themselves if they contented themselves in arriving at a decision with the information provided by the executive officers of the corporation (820099 Ontario Inc. v. Harold Ballard Ltd., 1991).

The obligation to inform oneself is not however limited to matters involving change of control transactions: "directors have been forced to adapt to ensure that they are fully informed of all requirements, operations, and considerations that ultimately govern their corporate decision-making capacity." (Reiter, 2009, p. 59). The Repap decision illustrates the scope of the obligation to inform oneself. In that case concerning the terms of an 
employment contract involving compensation that was considered excessive, the court held that the directors had the obligation to be scrupulous and diligent in making their decision. In this regard, it added that the courts could examine the information obtained and used by the directors: "Courts are entitled to consider the content of their decision and the extent of the information on which it was based and to measure this against the facts as they existed at the time the impugned decision was made." (Repap, para. 153) (CW Shareholdings Inc., 1998). In addition, the court noted that, while directors are encouraged to consult experts, such consultation did not have the effect of relieving them of their duty of care in making the decision. (Unique Broadband Systems, Inc. (Re), 2013). The directors were therefore required to maintain supervision over the preparation of the opinion on which they were likely to base their subsequent decision (Note 18).

The obligation to inform oneself is therefore well established in Canadian law (McGuinnes, 2007, p. 947). This obligation must be assessed in light of the objective the directors will be pursuing in making their decision, which consists of maximizing the value of the corporation (Note 19). This means that, when making decisions, the directors should ensure that they have the important information that is reasonably available concerning all of the considerations raised by the decisions that are to be made (Reiter, 2009, pp. 61-62) (Note 20). Thus, the information compiled by the directors should not be limited solely to the shareholder perspective, but should include the perspective of the other stakeholders particularly affected by the decision (Reiter, 2009, p. 652) (Note $21)$. And " $[\mathrm{w}]$ here the corporation is an ongoing concern", the information should be obtained on the basis of the long-term interests of the corporation (BCE Inc. at para. 38). Of course, the strength of the obligation to inform oneself will vary depending on the importance of the decision involved.

\subsection{Obligation of Fair Treatment}

In $B C E$, the Supreme Court ruled that the oppression remedy is relevant to the directors' duty of loyalty (Note 22). More specifically, the remedy has the effect of imposing an obligation on the directors to treat each stakeholder equitably and fairly when the directors are acting in the corporation's interests.

The cases on oppression, taken as a whole, confirm that the duty of the directors to act in the best interests of the corporation includes a duty to treat individual stakeholders affected by corporate actions equitably and fairly. There are no absolute rules. In each case, the question is whether, in all the circumstances, the directors acted in the best interests of the corporation, having regard to all relevant considerations, including, but not confined to, the need to treat affected stakeholders in a fair manner, commensurate with the corporation's duties as a responsible corporate citizen (BCE Inc. at para. 81-82).

In other words, the duty of loyalty has mandatory component taking the form of an obligation to treat the stakeholders fairly. The scope of this obligation is dependent on the reasonable expectations of the stakeholders.

According to the Supreme Court, "the concept of reasonable expectations is objective and contextual." (BCE Inc. at para. 62) Thus, "the question is whether the expectation is reasonable having regard to the facts of the specific case, the relationships at issue, and the entire context, including the fact that there may be conflicting claims and expectations." (BCE Inc.at para. 62) When such an expectation exists, the directors may not defeat it through conduct that amounts to oppression, unfair prejudice or unfair disregard of a relevant interest.

Nevertheless, the reasonable expectations must be determined on the basis of directors' duties (BCE Inc. at para. 64). This is necessary so that one can avoid the characterization of decisions as oppressive that were made by the directors in fulfillment of their duties. In this sense, the Supreme Court noted in $B C E$ that, in the event of a conflict between the interests of the corporation and the reasonable expectations of an interested party concerning a given result, the corporation's interests prevail: "the directors owe their duty to the corporation, not to stakeholders, and $[\ldots]$ the reasonable expectation of stakeholders is simply that the directors act in the best interests of the corporation." (BCE Inc. at para. 6)

The influence of the obligation of fair treatment on the directors' decision making relating to the stakeholders must not be overestimated (VanDuzer, 2010, p. 248 and following) (Martin, 2012). From a substantive viewpoint, the oppression remedy only protects the rights and interests of securities holders, creditors, officers and directors $(B C A Q, 2009$, s. 441) (CBCA, 1985, s. 241) (VanDuzer, 2010, p. 251). The scope of the remedy does not extend to the rights and interests of other stakeholders, such as the employees. From a procedural standpoint, these other stakeholders do not have an interest, as of right, to institute an oppression remedy (VanDuzer, 2010). In fact, studies have shown that the courts have rarely recognized that such stakeholders have the requisite interest to institute this remedy (Ben-Ishai \& Puri, 2004) (VanDuzer, 1993). In sum, the current state of the law is such that the obligation of fair treatment of stakeholders other than those enumerated in the statute is practically non-existent. 


\subsection{Business Judgment Rule}

The business judgment rule is a principle of deference guiding the courts in reviewing business decisions (Crête \& Rousseau, 2011, p. 474 and following). The deference has the effect of providing a shield to directors in the context of liability proceedings aimed at sanctioning breaches of the duty of care. Since the decision in $B C E$, judicial deference also protects the directors from challenges which contend that they did not make a decision in the interests of the corporation (BCE Inc. at para. 40) (Desalliers, 2009, at para. 26).

The judicial deference resulting from the application of the business judgment rule depends on two conditions. (Unique Broadband Systems, Inc. (Re), 2013). First, the decision-making process must provide solid evidence of a reasonably prudent and diligent process in making the decision. Some of the considerations that would substantiate such a process include the seriousness and duration of the deliberations and the obtaining of all reasonably accessible and relevant information for the decision.

The second condition involves the examination of the substance of the decision that was made. This substantive component of the rule entails a review of the reasonableness of the directors' decision.

In the $B C E$ case, the Supreme Court noted that judicial deference was called for when the merits of a business decision are under review (BCE Inc. at para. 40). Thus, judicial review consists of determining whether the directors made a reasonable decision and not the best decision (Maple Leaf Foods Inc. v. Schneider Corp., 1998) (Peoples, 2004, at para. 65) (Computershare Trust Company of Canada v. Crystallex International Corporation, 2009, at para. 97). Professor Eisenberg explained thus what an "unreasonable" decision would consist of:

[A] decision may be unreasonable if there are good reasons for and against the decision but under the circumstances a person of sound judgment, giving appropriate weight to the reasons for and against, would not have made the decision. Accordingly, a decision may be unreasonable even though it was supported by some affirmative reasons and was therefore explicable, although on balance objectively undesirable (Eisenberg, 1997, p. 584).

In summary, the business judgment rule gives directors the discretion to identify the interests of the corporation in concrete terms when making a specific decision. In other words, the rule limits the possibilities for contesting the definition of the corporate interest determined by the directors. However, this rule of deference requires that the directors have conducted a reasonable decision-making process, namely by acting in accordance with their obligation to inform themselves: "as a result of this new process-oriented emphasis, directors have been forced to adapt to ensure that they are fully informed of all the requirements, operations, and considerations that ultimately govern their corporate decision-making capacity" (Reiter, 2009, p. 59).

In conclusion, the risk of liability for directors will be greatest when they fail to adequately inform themselves of the impact of their decision, the decision is not reasonable as a result, and has detrimental consequences for the corporation's long-term value.

\subsection{Enforcement}

Since the obligation to inform oneself is derived from the duty of care, it is owed to the corporation, which is the beneficiary thereof. The corporation may sanction breaches through the institution of proceedings by the board of directors. Breaches of the obligation to inform oneself may also give rise to "derivative" action, instituted on behalf of the corporation, or to the oppression remedy. However, stakeholders (other than securities holders) cannot institute derivative action or oppression remedy as of right under the corporate legislation. Furthermore, as we noted above, the courts are still reticent to authorize such proceedings by the stakeholders. Therefore, legal proceedings by shareholders will likely be the means for sanctioning breaches of the obligation of directors to inform themselves. Proceedings could be instituted by shareholders based on the principle of the maximization of long-term value, by institutional investors applying a socially responsible investment strategy, or by stakeholders also holding shares of the corporation.

\section{A Framework for Corporate Governance in a Multi-Stakeholder Contexte}

\subsection{Analytical Framework}

We propose a decision-making framework in four steps for a board to fully discharge its responsibility under Canadian laws:

\section{1) Be explicit about how the decision to be made relates to the objective of maximizing the long-term value of the corporation}

The directors should have measures of the value of the corporation at their disposal and be able to connect the specific decisions to the maximization of that value. If the decision clearly serves the interests of shareholders, 
the directors should establish that these interests are aligned with the corporation's interests as a whole. In all cases, the directors have no obligation to act in the interests of each of the stakeholders, but rather, in the interests of the corporation.

\section{2) Adopt a rigourous decision-making process making use of all pertinent and reasonably available information}

The directors should adopt a fact-based, rigourous and explicit decision-making process. They should follow a logical and considered approach in the pursuit of the corporation's interests (In re Netsmart Techs., Inc. S'HolderLitig., 2007, p. 192). To do so, given that the notion of the corporation's interest is focused on maximizing the value of the firm, they should identify the stakeholders concerned and establish their level of relevance for the decision. To facilitate this exercise, the directors could draw up a list, in advance, of the stakeholders and the nature of their interests vis-à-vis the corporation (Mason \& Simmons, 2014). The directors will obtain the important information on the stakeholders either from the management team, the stakeholders themselves, or independent external advisors, as needed. This information will enable them to assess the costs and benefits of the various potential scenarios.

\section{3) Consider the reasonable expectations of stakeholders who may exercise remedies against the corporation}

When making decisions, the directors should identify the reasonable expectations of the stakeholders (including the shareholders) whose interests are specifically protected by the oppression remedy. While corporate law is not settled on this issue, it seems prudent for the directors to consider the reasonable expectations of all stakeholders in making their decision. Of course, stakeholders' reasonable expectations do not take precedence over the corporation's interests.

\section{4) Render a fact-based business judgment as to the course of action which best serves the long-term interest of the corporation}

With the information they have obtained, the directors should exercise their judgment by identifying a reasonable course of action to further the interests of the corporation, i.e. which contributes to maximizing the long-term value of the corporation. The directors should weigh the advantages and disadvantages of "several alternatives" for the corporation, and then choose the course of action which appears optimal for the corporation.

\subsection{Application: the Decision to Offshore Some of the Company's Operations}

To illustrate the application of our analytical framework, let us consider the example of a board of directors considering whether to close a plant and relocate production to another country (offshoring) where labour costs are seen as cheaper. According to the classical approach, the board of directors could limit its analysis to the impact of the reduction in costs on the short-term results of the corporation. This course of action would appear a desirable one, and in conformity with their duty of loyalty, if it led to an increase in profits for shareholders. Thus, the directors could limit their analysis to a comparative study of the data on production costs.

But, the approach proposed above calls for a more deliberate assessment. Firstly, the directors should set out the goals to be achieved by the offshoring of production and its contribution to the maximization of the company's long-term value.

Secondly, the directors should identify the stakeholders concerned-particularly the employees, shareholders, local communities and governments - and should compile the relevant information on the consequences of the offshoring decision on those stakeholders in the short and long term. Here are some of the relevant questions that board members might raise:

- What are the corporation's current returns (ROIC (return on invested capital) ROA 9return on assets), ROE (return on shareholders' equity)) and how would these returns be improved by the offshoring decision? How do these current returns compare with those of competitors and other relevant firms?

- What are the total costs associated with the offshoring, such as the costs of transferring management personnel and maintaining them abroad, training of local manpower, costs of monitoring, etc.?

- Have the corporation's competitors carried out similar offshoring of operations?

- Does the company currently suffer from a cost disadvantage vis-à-vis its key competitors? How vulnerable is the corporation because of its cost disadvantage? Is offshoring strictly a move to boost share price, but not a requirement for the firm's cost competitiveness or achieving an adequate financial performance?

- How have operating costs evolved over time in the offshoring destination countries? 
- What has been the experience of other corporations that undertook offshoring of production in the same countries?

- What are the social costs of employee lay-offs borne by the society where the operations to be offshored are presently located?

- Has the management held discussions with the affected personnel and unions to find alternative solutions and accommodations to avoid the offshoring?

- What are the reputational consequences of the offshoring decisions on future relations with governments, on future relations with employees and unions? What government support may be required by the corporation in the near future?

- What are the consequences of such decisions for the corporation's social legitimacy?

The information collected as a result of such inquiries will allow directors to assess various scenarios in full knowledge of the total costs, tangible and intangible, of the decision: the shutdown of the site and offshoring of production; a new deal with employees and unions to close the cost competitiveness gap and so on. In fine, directors must make the decision that will best contribute to the long-term welfare of the company.

Neither the interests of the shareholders, nor of the employees or other stakeholders should take precedence, per $s e$, in making this decision. The directors should carry out an arbitration of the various interests with a view to identifying a solution that appears reasonable to them and corresponds to the corporation's long-term interests.

\section{Conclusion}

According to the Canada Business Corporations Act, and the interpretation thereof by the Supreme Court of Canada in two recent decisions, the boards of directors of Canadian corporations must act in the interests of the corporation without favouring any particular stakeholder, not even the shareholders. However, the Canadian statute identifies the stakeholders by name that have a right to the "oppression remedy": the security holders, creditors, directors and officers.

Thus, the Supreme Court enjoins corporate boards to make decisions in the long-term interests of the corporation, without favouring any stakeholder, but gives no remedies to the stakeholders (other than the shareholders, creditors, directors and officers) if they feel aggrieved by a decision.

This is a major flaw in the Supreme Court's decisions. On the one hand, the Court is generous to stakeholders in its definition of the corporation's interests. On the other hand, whether by omission or inadvertence, it fails to correct the fact that several key stakeholders have no access to the available remedies under the CBCA. Ultimately, this omission limits the effectiveness of the Court's decisions in favour of the stakeholders

However, proceedings could be instituted on behalf of these "omitted stakeholders" by shareholders invoking the long-term interest of the corporation, by institutional investors invoking a socially responsible investment strategy, or by labour unions holding shares of the corporation.

Furthermore, in matters of unsollicited, or hostile, takeover attempts, the logic of the Canada Business Corporations Act and the Supreme Court decisions interpreting the act clearly giveto boards of directors of any federally (or Quebec) incorporated corporation the power and the authority to assess and reject such a takeover attempt if the board establishes that in its busness judgment such a takeover will not further the long-term interest of the corporation.

Yet Canadian securities commissions have taken upon themselves to curtail the power of the boards of directors by imposing on them restrictions and different obligations. The legal authority of securities commissions to enact policy instruments running afoul the Supreme Court's decisions should be subjected to a legal challenge. Whenever a company is targeted for hostile takeover, its board should ask the courts to invalidate the policy instruments of securities commissions which in fact prevent directors from fulfilling their fiduciary responsibilities as defined in Canadian laws and Supreme Court decisions.

Canadian boards of directors will be well advised to take into consideration the interests of a body of stakeholders in their deliberations surrounding a major decision, be they a takeover, offshoring or any other type of decision.

Canadian law also imposes a responsibility on the directors to be informed. To fulfill their duty of care, the directors have the obligation to inform themselves adequately about the decision to be made by obtaining all the important information that is reasonably available in the circumstances. In the contemporary context of search 
engines and the profusion of easily accessible sources of information, the obligation to review "all reasonably available information" sets the bar of the board's responsibility at a high level.

The risk of the liability for the directors will be greatest when they fail to adequately inform themselves of the impact of their decision on all of the stakeholders and, as a result, the decision is not reasonable and has detrimental consequences for the corporation.

Directors are encouraged to consult experts, but such consultation does not have the effect of relieving them of their obligation of care when the decision is made. The directors are also required to maintain supervision of the preparation of the opinion on which they are likely to base their subsequent decision.

We propose a four-step process for corporate boards to fulfill their responsibility to the corporation, which also takes the reasonable expectations of the stakeholders into account:

1) Be explicit about how the decision to be made relates to the objective of maximizing the long-term value of the corporation

2) Adopt a rigourous decision-making process making use of all pertinent and reasonably available information

3) Consider the reasonable expectations of stakeholders who may exercise remedies against the corporation

4) Render a fact-based business judgment as to the course of action which best serves the long-term interest of the corporation

\section{References}

Allaire, Y., \& Firsirotu, M. (1993). L'entreprise stratégique: penser la stratégie. Montreal, QC: Gaétan Morin.

Allaire, Y., \& Firsirotu, M. (2007). Hedge Funds: Passing Phenomenon or Grave-Diggers of Public Corporations? http://dx.doi.org/10.2139/ssrn.961828

Allaire, Y., \& Firsirotu, M. (2009a). Black Markets... and Business Blues. Montreal, QC: FI Press.

Allaire, Y., \& Firsirotu, M. (2009b). Plaidoyer pour un nouveau capitalisme. Montreal, QC: IGOPP.

Allaire, Y., \& Firsirotu, M. (2004). Stratégies et moteurs de performance. Montreal, QC: Chenelière-McGraw Hill.

Armstrong World Industries Inc. c. Arcand, 1997 O.J. No 4620. (O.C.J.).

Aronson v. Lewis, 473 A.2d 805, 812 (Del. 1984)

Baron v. Strawbridge, 646 F. Supp. 690 (E.D. Pa. 1986)

BCE Inc. c. Détenteurs de débentures de 1976, 2008 CSC 69.

Beale, P. (2007, July 20). Directors Beware. New Law Journal.

Ben-Ishai, S. \& Puri, P. (2004). The Canadian Oppression Remedy Judicially Considered: 1995-2001. Queen's Law Journal, 30, 79-113.

Blair c. Consolidated Enfield Corp., 19954 R.C.S. 5.

Bradley, M., Shipani, C. A., Sundaram, A. K., \& Walsh, J. P. (1999). The Purposes and Accountability of the Corporation in Contemporary Society: Corporate Governance at a Crossroads. Law \& Contemporary Problems, 62(3), 9-86. http://dx.doi.org/10.2307/1192226

Brassard c. Forget, 2010 QCCS 1530.

Brehm v. Eisner, 746 A.2d 244, 259 (Del. 2000).

Carlson Family Trust v. MPL Communications Inc., 2009 ABQB 77.

Computershare Trust Company of Canada c. Crystallex International Corporation, 2009 ON S.C. 71007.

Corporacion Americana de EquipamientosUrbanos S.L. v. Olifas marketing group Inc., 2003 ON S.C. 22758.

Crête, R., \& Rousseau, S. (2011). Droit des sociétés par actions (2nd ed.). Montréal, QC: ÉditionsThémis.

CW Shareholdings Inc. v. WIC Western International Communications Ltd., 1998 ON S.C. 14838.

Davies, J. (2007). A Guide to Directors Obligations Under the Companie Act 2006.Association of Chartered Certified Accountants. Retrieved from http://www.accaglobal.com/content/dam/acca/global/PDF-technical/business-law/tech-tp-cdd.pdf

Desalliers, P. (2009). Responsabilité des administrateurs en vertu du droit commun. In S. Rousseau (Ed.), Droit 
des sociétés, Jurisclasseur Québec - coll. Droit des affaires. Montreal, QC: LexisNexis.

Dodge v. Ford Motor Co., 170 N.W. 668, 683 (Mich. 1919).

Ebay Domestic Holdings, Inc. v. Newmark, 16 A.3d 1 (Del. Ch. 2010).

Eisenberg, M. A. (1997). The Directors' Duty of Care in Negociated Dispositions.U. Miami Law Review, 51, 579-604.

Goodpaster, K. E. (1991). Business Ethics and Stakeholder Analysis. Business Ethics Quarterly, 1(1), 53-73.

Gray, W. D. (2005). A Solicitor's Perspective on Peoples v. Wise.Can. Bus. L.J., 41, 184-199.

Greenhalgh c. Ardene Cinemas Ltd., [1951] Ch. 286 (C.A.)

Greenlight Capital Inc. c. Stronach, 2006 ON S.C. 36620.

Hu, H. (1991). New Financial Products, the Modern Process of Financial Innovation, and the Puzzle of Shareholder Welfare. Texas L. Rev., 69, 1273-1317.

Hu, H., \& Black, B. S. (2006). Empty Voting and Hidden (Morphable) Ownership: Taxonomy, Implications, and Reforms. Business Lawyer, 61, 1011-1070.

Iacobucci, E. (2003). Directors' Duties in Insolvency: Clarifying What Is at Stake. Can. Bus. L.J., 39, 398-411.

In re Netsmart Techs., Inc. S'HolderLitig., 924 A.2d 171, 192 (Del. Ch. 2007).

Keay, A. (2013). The Enlightened Shareholder Value Principle and Corporate Governance. London: Routledge.

Keyser v. Commonwealth National Financial Corp., 675 F. Supp. 238, 265 (M.D. Pa. 1987).

Lazonick, W., \& O'Sullivan, M. (2000). Maximizing Shareholder Value: A New Ideology for Corporate Governance. Economy and Society, 29, 13-35. http://dx.doi.org/10.1080/030851400360541

Lizée, M. (1989). Le principe du meilleur intérêt de la société commerciale en droit anglais et compare. McGill L.J., 34, 653-684.

Magasins à rayons Peoples Inc. (Syndic de) c. Wise, 2004 CSC 68.

Maple Leaf Foods Inc. c. Schneider Corp., 1998 ON C.A. 5121.

Martel, M., \& Martel, P. (2013). La société par actions au Québec - les aspects juridiques. Montreal, QC: Éditions Wilson \& Lafleur Martel ltée.

Martin, I. (2012). The Impact of the Regulatory Environment on the Definition of the Best Interests of the Corporation. http://dx.doi.org/10.2139/ssrn.2247434

Mason, C., \& Simmons, J. (2014). Embedding Corporate Social Responsibility in Corporate Governance: A Stakeholder Systems Approach. Journal of Business Ethics, 119, 77-86. http://dx.doi.org/10.1007/s10551-012-1615-9

McGuinness, K. P. (2007). Canadian Business Corporations Law (2nd ed.). Toronto, ON: Lexis Nexis.

Millon, D. (2011). Two Models of Corporate Social Responsibility. Wake Forest Law Review, 30, 523-540.

Mitchell, L. E. (1992). A Theoretical and Practical Framework for Enforcing Corporate Constituency Statutes. Texas Law Review, 70, 579-643.

Nickerson, S. S. (1998). The Sale of Conrail: Pennsylvania's Anti-Takeover Statute versus Shareholder Interests. Tulane Law Review, 72, 1369-1420.

Orts, E. W. (1992). Beyond Shareholders Interpreting Corporate Constituency Statutes. GeorgeWashington Law Review, 61, 14-135.

Palmer c. Carling O'Keefe Breweries of Canada Ltd., 198967 O.R. (2d) 161, H.C.

Paramount Communications, Inc. v. Time Inc., 571 A.2d 1140, 1153 (Del. 1990).

Parke v. Daily News Ltd. (1962) Ch 927.

Pente Investment Management Ltd. v.Schneider Corp., 1998113 O.A.C.

Peoples Department Stores Inc. c. Wise, 2003 Q.J. No. 505, (QL) (Q.C.A.).

Raffo c. Teknorordinateursindustriels Inc., [2000] J.Q. No 986 (Q.L.) (C.S.).

Re Olympia \& York Entreprises Ltd.c. Hiram Walker Resources Ltd., (1986) 59 O.R. (2d) 254 (Ont.H.C.J.) 
Reiter, B. (2009). Directors' Duties in Canada (4th ed.). Toronto, ON: CCH.

Revlon Inc. v. MacAndrews \& Forbes Holdings, Inc., 506 A.2d 173 (Del. 1986).

Sealy, L. (1996). Perception and Policy in Company Law Reform. In D. Feldman \& F. Meisel (Eds.), Corporate and Commercial Law: Modern Developments. London: Lloyd's of London Press.

Shlensky v. Wrigley, 237 N.E. 2d. 776 (III. App. Ct. 1968).

Smith v. Van Gorkom, 488 A.2d 858, 874 (Del. 1985).

Sneirson, J. F. (2007). Doing Well By Doing Good: Leveraging Due Care for Better, More Socially Responsible Corporate Decisionmaking. Corporate Governance Law Review, 3, 438. http://dx.doi.org/10.2139/ssrn.970359

Springer, J. D. (1999). Corporate Constituency Statutes: Hollow Hopes and False Fears. Annual Survey of American Law, 85-128.

Symposium: corporate malaise: Stakeholder statutes: cause or cure?. (1991). St. Petersburg, Fla: Stetson University College of Law.

TELUS Corporation (Re), 2012 BCSC 1919.

Unique Broadband Systems, Inc. (Re), 2013 ONSC 2953.

UPM-Kymmene Corp. c. UPM-KymmeneMiramichi Inc., (2002) 27 B.L.R. (3d) 53 (C.S. Ont.)

Van Duzer, A. J. (2010). BCE v. 1976 Debentureholders: The Supreme Court's Hits and Misses in Its Most Important Corporate Law Decision since Peoples. U.B.C. Law Review, 43, 205-258.

VanDuzer, A. J. (1993). Who May Claim Relief from Oppression: The Complainant in Canadian Corporate Law. Ottawa Law Review, 25, 463-484.

Veasey, N. E. (2010). The Challenges for Directors in Piloting Through State and Federal Standards in the Maelstrom of Risk Management. Seattle Law Review, 34, 1-16.

Waitzer, E. J., \& Jaswal, J. (2009). Peoples, BCE, and the Good Corporate "Citizen". Osgoode Hall Law Journal, 47, 439-496.

Wallman, S. M. H. (1991). The Proper Interpretation of Corporate Constituency Statutes and Formulation of Directors Duties. Stetson Law. Review, 21, 163-196.

Westfair Foods Ltd.c. Watt, [1990] A.J. No. 315 (Q.L.) (A.C.Q.B.).

1394943 Ontario Inc. v. Roy, [2009] O.J. 922 (Ont. S.C.).

820099 Ontario Inc. c. Harold Ballard Ltd., (1991) 3 B.L.R. (2d) 123 (C.S.Ont.).

\section{Notes}

Note 1 . As is the case in some 30 U.S. states, where legislatures, driven to action by the waves of hostile takeovers in the 1980s, granted boards the authority, and sometimes the duty, to take the interests of multiple stakeholders into account in assessing whether or not a takeover bid should be accepted or rejected.

Note 2. In doing so, the court cited the teachings in the famous case of Dodge v. Ford Motor Co., 1919, p. 683.

Note 3. See also Revlon Inc. v. MacAndrews \& Forbes Holdings, Inc., 1986, p. 183 (“Although such considerations [of non-stockholder corporate constituencies and interests] may be permissible, there are fundamental limitations upon that prerogative. A board may have regard for various constituencies in discharging its responsibilities, provided there are rationally related benefits accruing to the stockholders").

Note 4. In the context of a change of control transaction, the Delaware case law has however developed a standard of conduct based on the short-term maximization of share value (Revlon Inc. v. MacAndrews \& Forbes Holdings, Inc., 1986).

Note 5. In the Delaware decision in Time, the court noted as follows: "The fiduciary duty to manage a corporate enterprise includes the selection of a time frame for achievement of corporate goals. That duty may not be delegated to the stockholders". (Paramount Communications, Inc. v. Time Inc., 1990). See also Shlensky v. Wrigley, 1968.

Note 6 . The Telus case is a good illustration of the difficulties raised by the use of derivative products in defining the shareholders' interests. See TELUS Corporation (Re), (2012). 
Note 7. See David Millon who refers to the "Sustainability Model of CSR": "The connection between sustainability and CSR is simply the realization that the corporation's long-run prosperity depends on the well-being of its various stakeholders, including workers, suppliers, and customers.

Note 8 . In the name of "creating shareholder value", the past two decades have witnessed a marked shift in the strategic orientation of top corporate managers in the allocation of corporate resources and returns away from "retain and reinvest" and toward "downsize and distribute".

Note 9. To this effect, the Supreme Court cited professor Iacobucci, who defines the value of the corporation as follows: In such a world it would be clear to whom directors should owe their duties: to investors collectively, maximizing the sum of shareholder and creditor value. Put another way, the director would owe a duty to maximize the market value of the corporation (Iacobucci, 2003).

Note 10. Pennsylvania Statutes and Consolidated Statutes Annotated, Title 15, Corporations and Unincorporated Associations.

Note 11. Except, of course, that in Canada the securities commissions have arrogated the right to intervene to themselves to remove all authority from the board during attempts to take control of the corporation of which they are directors!

Note 12. It is certainly interesting to note that, in Delaware, in the context of the Unocal standard, the courts recognized that the protection of the corporate interest could be assessed on the basis of the stakeholders' interests. See, for example, Paramount Communications, Inc. v. Time Inc., 1990. Recently, in the eBay decision, the Court of Chancery sought however to temper this interpretation.

Note 13. Given the objective of our study, we do not intend to comment on each of these factors. See Andrew Keay, 2013, pp. 111-128.

Note 14. Art. 322 C.C.Q.; art. 119 Quebec BCA; s. 122 CBCA. See Crête \& Rousseau, 2011, at p. 392.

Note 15. See, for example, Industry Canada, CSR Governance Guidelines. Retrieved from https://www.ic.gc.ca/eic/site/csr-rse.nsf/eng/h_rs00577.html. See also Choc v. Hudbay Minerals Inc., 2013 ONSC 1414.

Note 16. See, in the United States, Aronson v. Lewis, 1984 and Veasey, 2010.

Note 17. See also Brehm v. Eisner, 746 A.2d 244, 259 (Del. 2000) ("[I]n making business decisions, directors must consider all material information reasonably available).

Note 18. In Repap, Justice Lax found that the members of the compensation committee, who had the prime responsibility for this role, had not supervised the preparation of Mercer's opinion.

Note 19. The interpretation of the obligation to inform oneself that we are proposing does not however create an obligation to consider the interests of the stakeholders, but rather to obtain the relevant information about them for making the decision. We note that the $B C E$ decision is ambiguous on the existence of such an obligation. (Waitzer \& Jaswal, 2009, p. 475) (Van Duzer, 2010, p. 244).

Note 20. In this regard, it is interesting to note the following passage from the $B C E$ decision: "Directors, acting in the best interests of the corporation, may be obliged to consider the impact of their decisions on corporate stakeholders, such as the debentureholders in these appeals."

Note 21. Under U.S. law, the scope of the obligation to inform oneself in relation to the stakeholders is discussed by Sneirson, 2007. So while stakeholder assessments will require some amount of time and effort, better informed decisions will result, and those decisions have the potential to be both more socially responsible and more likely to maximize the long-term value of the firm.

Note 22. The oppression remedy is set out in section 450, Business Corporations Act, CQLR, c. S-31.1 ("BCAQ") and section 241, Canada Business Corporations Act, R.S.C., c. C-44 ("CBCA"). On this remedy, see Martel \& Martel, 2013, at paras. 31-134 and following.

\section{Copyrights}

Copyright for this article is retained by the author(s), with first publication rights granted to the journal.

This is an open-access article distributed under the terms and conditions of the Creative Commons Attribution license (http://creativecommons.org/licenses/by/3.0/). 